\title{
Examining the Social Anxiety of University Students in Synchronous Online Learning Environments
}

\section{Üniversite Öğrencilerinin Senkron Öğrenme Ortamlarındaki Sosyal Kaygılarının İncelenmesi}

\author{
Ekrem Bahçekapılı1 (i)
}

(Assist. Prof), Karadeniz Technical University, Faculty of Economics \& Administrative Sciences, Department of Management Information Systems, Trabzon, Turkey

ORCID: E.B. 0000-0002-7538-1712

Corresponding author:

Ekrem BAHCEKAPILI

Karadeniz Technical University, Faculty of

Economics \& Administrative Sciences,

Department of Management Information Systems,

Trabzon, Turkey

E-mail address: ekrem.bahcekapili@ktu.edu.tr

Submitted: 08.05 .2021

Revision Requested: 16.06 .2021

Last Revision Received: 23.06.2021

Accepted: 16.07.2021

Published Online: 27.10 .2021

Citation: Bahcekapili, E. (2021). Examining the social anxiety of university students in

synchronous online learning environments. Acta

Infologica, 5(2), 435-443.

https://doi.org/10.26650/acin. 934636

\begin{abstract}
This study examines the social anxiety of university students in online live lessons in terms of their digital literacy levels, gender, previous distance education experiences, and the way they interact with the teacher in live lessons. The study was conducted with a causal-comparative and correlational research design. Data was obtained from 167 university students with an online questionnaire. The instruments used in the study were the general information form, the student-teacher interaction subscale of the social anxiety scale in e-learning environments, and the digital literacy scale. The data analysis was carried out with correlation analysis and an independent sample t-test. Results of the research showed that the social anxiety of students in synchronous learning environments has a negative relationship with their digital skills. The social anxiety of female students was found to be higher than male students. Also, students who did not actively listen to the lesson and interact with the teacher through live chat were more anxious. The social anxiety did not differ according to previous distance education experience and the use of microphones in lessons.
\end{abstract}

Keywords: Social Anxiety, Synchronous Online Learning Environments, Digital Literacy, Interaction

ÖZ

Bu çalışmada üniversite öğrencilerinin çevrimiçi canlı derslerdeki sosyal kaygılarının dijital okur-yazarlık düzeyleri, cinsiyetleri, önceki uzaktan eğitim deneyimleri ve canlı derslerde öğretmenle etkileşime geçme şekilleri açısından incelenmesi amaçlanmaktadır. Nedensel karşılaştırmalı ve ilişkisel araştırma deseninde gerçekleştirilen çalışmanın katılımcılarını 167 Üniversite öğrencisi oluşturmaktadır. Veriler online anket şeklinde elde edilmiştir. Çalışmada genel bilgi formu, e-öğrenme ortamlarında sosyal kaygı ölçeğinin öğrenci-öğretmen etkileşimi alt ölçeği ve dijital okur yazarlık ölçeği kullanılmıştır. Verilerin analizi korelasyon analizi ve bağımsız t-testi ile gerçekleştirilmiştir. Araştırma sonuçları öğrencilerin senkron öğrenme ortamlarındaki sosyal kaygılarının dijital becerileri artııça azaldığını, kız öğrencilerin erkek öğrencilere göre daha kaygılı olduklarını, dersi aktif dinlemeyen ve canlı sohbet yoluyla öğretmenle etkileşime geçmeyen öğrencilerin daha kaygılı olduğu göstermektedir. Ayrıca sosyal kaygı önceki uzaktan eğitim deneyimi ve derslerde mikrofon kullanımına göre farklılaşmadığı bulunmuştur.

Anahtar kelimeler: Sosyal Kaygı, Eşzamanlı Çevrimiçi Öğrenme Ortamları, Dijital Okuryazarlık, Etkileşim 


\section{INTRODUCTION}

The development of Information Technology (IT) in higher education is becoming more apparent, especially with online learning applications. Online learning expands students' access to information and provides a flexible learning experience by removing many of the physical limitations of the face-to-face learning environment (Kumar Basak et al., 2018). Online learning has emerged as a powerful alternative to ensure continuity of education, especially in the Covid 19 pandemic (Radha et al., 2020).

Moore's Transactional Distance Theory guides this study. The physical distance between learners and teachers in distance education also creates a perception of psychological space (Moore, 1997). This theory emphasizes that students' characteristics (personality, experience, needs, expectations, etc.) are critical elements in this process. Other crucial factors are instructor characteristics, technology infrastructure, e-learning systems, online learning resources, support and training (Alhabeeb \& Rowley, 2018). As in all learning environments, there are students at the center of distance education. Critical concepts for all these factors in online learning are communication and interaction (Chou, 2003). Interaction and communication may directly affect many pedagogical factors such as students' motivation, satisfaction, continuing education, and academic success.

There are different types of interaction in online learning environments. These can be classified as student-student, studentteacher, student-content, student-interface (Hillman et al., 1994). In addition, it can be classified as synchronous and asynchronous learning according to the time of interaction and communication. If interaction and communication take place in real-time, it is called synchronous education; if it is independent of time, it is called asynchronous education.

During Covid 19, the most popular online learning method for teaching is synchronous learning. With synchronous learning, real-time communication and interaction are usually provided between students and teachers with video conferencing, chat, and whiteboard features. Synchronous learning applications are seen as the closest teaching method to face-to-face teaching (Stewart et al., 2011), and it is thought to increase presence and social interaction more than other distance education methods (Johnson, 2006). However, some problems arising from technical skills, infrastructure, internet connection (Park \& Bonk, 2007), and student and teacher behavior (Warden et al., 2013) may cause problems such as low participation and inability to obtain the expected learning experience (Orhan \& Beyhan, 2020).

Social anxiety is an essential factor that affects online interaction (Hutchins et al., 2021). Social anxiety may also affect students' success in online learning environments (Ajmal \& Ahmad, 2019). Social anxiety disorder is defined as the "fear of appearing clumsy and stupid or embarrassing." (Morrison, 2016). Social anxiety could lead to avoiding excessive and exaggerated social situations due to a fear of negative evaluation by others (Persons \& Tompkins, 2011). While the anonymity of individuals is preserved more in asynchronous communication-based interactions, the real characters of individuals are more prominent in synchronous communication methods. This situation may cause individuals to be more controlled in online synchronous communication environments and increase the possibility of anxiety (Amichai-Hamburger \& Furnham, 2007). Studies conducted in online learning environments also support this theory (Coryell \& Clark, 2009; Pierce, 2009).

The literature emphasizes different variables related to social anxiety in online environments. Studies show that previous e-learning experiences reduce anxiety and students have a more comfortable learning experience (Sharifrazi, 2012; Song, 2005; Song et al., 2004). Students' technology use skills and digital self-efficacy appear to be significant in reducing anxiety (Hill et al., 2009; Saadé \& Kira, 2009; Yang et al., 2010). Another finding that may be related to social anxiety in online learning environments is that digital skills reduce autonomy anxiety in online environments. (Korucu \& Gürkez, 2019). Gender is also an important variable in e-learning environments, and students' anxiety may vary according to gender. (Fawaz $\&$ Samaha, 2021; Wongwatkit et al., 2020). However, studies in the literature show no consensus on how anxiety arises in terms of gender in e-learning environments. Some studies indicate that females are more anxious than males in online communication environments (Ağırtaş \& Güler, 2020; Aktan, 2018; Saadé et al., 2017), while some studies state that for computer anxiety, there is no difference in terms of gender (Havelka et al., 2004). Communication type may affect social anxiety in online learning environments. Studies showed that different communication types affected students' social anxiety in online learning (Chen \& Lee, 2011; Fuller et al., 2006; Satar \& Özdener, 2008). 
When the current literature was examined, most of the studies in learning environments focused on student anxiety in asynchronous learning environments (Rapp-McCall \& Anyikwa, 2016; Reagan, 2018). These studies revealed that students' social anxiety was reduced more in asynchronous learning environments than in face-to-face learning environments (Grieve et al., 2017). Depending on the advances in web and communication technologies, the development of real-time applications has made simultaneous learning environments widespread. The communication dynamics of synchronous learning environments improve students' sense of presence in this environment (Gündüz et al., 2018) and may be perceived as socially threatening. This situation makes it essential to understand the social communication concerns of students in synchronous learning environments. A better understanding of social anxiety as a feature that affects communication and interaction in online synchronous learning environments may contribute to the design of more effective learning environments, the development of effective e-learning pedagogies, and the organization of learning environments for practitioners.

Anxiety is an important variable that negatively affects student performance in live lesson applications (D’Errico et al., 2016). This study examined how social anxiety, which has been revealed by different studies and can affect the communication of students with their teachers in synchronous learning environments, was affected by various variables such as digital literacy (Saadé \& Kira, 2009), gender (Fawaz \& Samaha, 2021), distance education experience (synchronous or asynchronous) (Sharifrazi, 2012), and communication types (Satar \& Özdener, 2008). For this purpose, answers to the following questions were sought:

1. Is there any correlation between social anxiety and digital literacy?

2. Is there a statistically significant difference between the social anxiety scores of females and males?

3. Is there a statistically significant difference between the participants' previous synchronous lesson experiences in terms of social anxiety scores?

4. Is there a statistically significant difference between attending e-lessons in terms of social anxiety scores?

5. Is there a statistically significant difference between students' not listening to teachers actively at live synchronous lessons regarding social anxiety scores?

6. 6. Is there a statistically significant difference between using chat in synchronous lessons and social anxiety?

7. Is there a statistically significant difference between using a microphone in synchronous lessons and social anxiety?

\section{METHOD}

To understand the relationship between students' digital literacy levels and social anxiety in synchronous learning environments, a correlational research design was preferred, and a causal-comparative design was preferred to understand how social anxiety differs in terms of gender, prior e-learning experience, and communication styles with the teacher. Causal comparative research focuses on making group comparisons, and correlational research, while on the other hand, provides an estimation of the relationship between two variables (Mertens, 2010).

\subsection{Participants}

The population of this research consists of university students studying in Turkey and receiving education through synchronous e-learning. Due to the difficulties in reaching the participants during the Covid 19 pandemic, the convenience sampling type was preferred (Gürbüz \& Şahin, 2018). This study tried to attain the maximum number of participants that could be reached with an online data collection tool. Accordingly, data were obtained from 185 participants. In the preliminary analysis, outlier incomplete and problematic data were deleted from the data set. As a result, 167 university students $49.1 \%$ female $(\mathrm{n}=82)$ and $50.9 \%$ male $(n=85)$ were included in the study. The institutional review board approved the study of Karadeniz Technical University Institute of Social Sciences (Document Number No: E-26014373-050.01.04-114067). 


\subsection{Measures and instruments for data collection}

\section{General Information Form}

The study obtained some general information related to synchronous lessons from the participants. This information included gender (female, male), previous e-learning experience (yes, no), previous synchronous lesson experience (yes, no), using chat in synchronous lessons (yes, no), using microphones in synchronous lessons (yes, no) is active listening to the teacher in synchronous lessons (yes, no).

\section{The Social Anxiety Scale for E-Learning Environments}

The Social Anxiety Scale for E-Learning Environments (SASE) was developed by Keskin et al. (2020) as two subscale forms to determine the levels of social anxiety in student-student interaction and learner-teacher interaction in online learning environments. In this study, the student-instructor sub-form was used. The scale consists of 23 items and three dimensions. These are Negative Assessment (NA), Somatic Symptoms (SS), and Avoidance of Interaction (AI). The scale is designed as a 7-point scale tool (from 1 = "Doesn't describe me at all" to 7 = "It fully describes me"). A high score on this scale indicates high levels of social anxiety in the relevant dimensions. The Cronbach Alpha value regarding the reliability of the original scale was found to be at least 0.93 in the sub-factors. In this study, the Cronbach alpha reliability value of the scale was acceptable level $(\alpha=0.97)$.

\section{Digital Literacy Scale}

The Digital Literacy Scale (DL) was used to determine the digital literacy levels of university students. The scale was adapted in Turkish by Üstündağ et al. (2017). The scale includes 10 items in a single factor and explains $40 \%$ of the total variability. The scale is designed as a 5-point Likert mode (from 1= "Strongly disagree" to 5="Strongly agree"). A high score on this scale indicates high levels of digital literacy skills. The Cronbach Alpha value regarding the reliability of the original scale was found to be 0.86 . In this study, the Cronbach alpha reliability value of the scale was at an acceptable level $(\alpha=0.97)$.

\subsection{Data analysis}

In data analysis, the data was pre-processed, and the contradictory and problematic data was cleaned. Correlation analysis for research question 1 and Independent Sample T-Test was performed for 2-7 questions. Data were analyzed using JASP software (JASP Team, 2020).

\section{FINDINGS}

\subsection{Is there any correlation between social anxiety and digital literacy?}

The Pearson correlation test analyses were conducted to examine the correlation level between the students' social anxiety and digital literacy scale scores (See Table 1). The results reveal that social anxiety sub-factors have a negative small significant correlation with the digital literacy scale.

Table 1

Pearson's Correlations for social anxiety and digital literacy

\begin{tabular}{llll}
\hline & NE & SS & AI \\
\hline NE & - & & DL \\
SS & $.77 * * *$ & - & - \\
AI & $.79 * * *$ & $.79 * * *$ & $-.28 * * *$ \\
DL & $-.22 * *$ & $-.23 * *$ & - \\
\hline
\end{tabular}

Note. The skewness values of each variable ranged from -0.82 to +0.75 while the kurtosis values ranged from -0.93 to -0.11 . This indicates that a normal distribution is achieved (Tabachnick \& Fidell, 2013). NE: Negative evaluation, SS: Somatic symptoms, AI: Avoidance of interaction, DL: Digital Literacy, $* \mathrm{p}<.05, * * \mathrm{p}<.001, * * * \mathrm{p}<.001$

\subsection{Is there a statistically significant difference between the social anxiety scores of females and males?}

Independent sample t-Test was used to test for social anxiety factors among students' gender (See Table 2). Social anxiety 
factors' scores for students differ significantly, [NE: $t(165)=-2.60, \mathrm{p}=.01, \mathrm{~d}=.27$; SS: $t(154)=-4.31, \mathrm{p}<.001, \mathrm{~d}=.29$; AI: $t(152)=-$ $2.60, \mathrm{p}=.01, \mathrm{~d}=.27]$. The female group's sub-factors of social anxiety were significantly higher than the male group with the medium Cohen's $d$ effect size (Privitera, 2012, p.246). These findings show that female students' anxiety about communicating with the teacher in e-learning environments is significantly higher than male students.

Table 2

Means, standard deviations, and t-test analyses of gender on three social anxiety factor scores

\begin{tabular}{|c|c|c|c|c|c|c|c|}
\hline & \multicolumn{4}{|c|}{ Gender } & \multirow[b]{3}{*}{$\mathrm{df}$} & \multirow[b]{3}{*}{$\mathrm{t}$} & \multirow[b]{3}{*}{ Cohen's d } \\
\hline & \multicolumn{2}{|c|}{ Female $(n=82)$} & \multicolumn{2}{|c|}{ Male $(n=85)$} & & & \\
\hline & M & SD & M & $\mathrm{SD}$ & & & \\
\hline NE & 3.82 & 1.82 & 3.13 & 1.61 & 165 & $-2.60 *$ & -0.40 \\
\hline SS & 3.59 & 2.11 & 2.31 & 1.67 & 154 & $-4.31 * *$ & -0.67 \\
\hline AI & 3.3 & 1.93 & 2.6 & 1.48 & 152 & $-2.60 *$ & -0.40 \\
\hline
\end{tabular}

Note. The skewness values of each variable ranged from +0.17 to +1.44 while the kurtosis values ranged from -1.41 to +1.28 . This indicates that a normal distribution is achieved (Tabachnick \& Fidell, 2013). NE: Negative evaluation, SS: Somatic symptoms, AI: Avoidance of interaction, * used for p $<.05$, *** for $\mathrm{p}<.01$

\subsection{Is there a statistically significant difference between the participants' previous synchronous lesson experiences in terms of social anxiety scores?}

An independent sample t-Test was used to test any difference between social anxiety factors and students' previous synchronous lessons experience (See Table 3). Social anxiety factors' scores for students do not differ significantly, [NE: $t(111)=-.97$, $\mathrm{p}=.34, \mathrm{~d}=.28$; SS: $t(165)=-.90, \mathrm{p}=.37, \mathrm{~d}=.29 ;$ AI: $t(165)=-.83, \mathrm{p}=.41, \mathrm{~d}=.32]$.

Table 3

Means, standard deviations, and t-test analyses of students' previous synchronous lessons experience on three social anxiety factors scores

\begin{tabular}{|c|c|c|c|c|c|c|c|}
\hline \multicolumn{8}{|c|}{ Previous synchronous lessons experience } \\
\hline & \multicolumn{2}{|c|}{ Yes $(n=51)$} & \multicolumn{2}{|c|}{ No $(n=116)$} & \multirow[b]{2}{*}{ df } & \multirow[b]{2}{*}{$\mathrm{t}$} & \multirow[b]{2}{*}{ Cohen's d } \\
\hline & M & SD & M & SD & & & \\
\hline $\mathrm{NE}$ & 3.28 & 1.56 & 3.55 & 1.82 & 111 & -0.97 & -0.16 \\
\hline SS & 2.75 & 1.81 & 3.02 & 2.07 & 165 & -0.90 & -0.15 \\
\hline AI & 2.76 & 1.55 & 3.02 & 1.83 & 165 & -0.83 & -0.14 \\
\hline
\end{tabular}

Note. The skewness values of each variable ranged from +0.38 to +0.85 while the kurtosis values ranged from -1.07 to -0.10 . This indicates that a normal distribution is achieved (Tabachnick \& Fidell, 2013). NE: Negative evaluation, SS: Somatic symptoms, AI: Avoidance of interaction

\subsection{Is there a statistically significant difference between attending e-lessons in terms of social anxiety scores?}

An independent sample t-Test was used to test if any difference existed between social anxiety factors and students' previous e-learning experience (See Table 4). Social anxiety factors' scores for students do not differ significantly, [NE: $t(165)=-.77$, $\mathrm{p}=.45, \mathrm{~d}=.33$; SS: $t(165)=-1.07, \mathrm{p}=.29, \mathrm{~d}=.33$; AI: $t(165)=-1.59, \mathrm{p}=.11, \mathrm{~d}=.37]$.

Table 4

Means, standard deviations, and t-test analyses of students' previous e-learning experience on three social anxiety factors scores

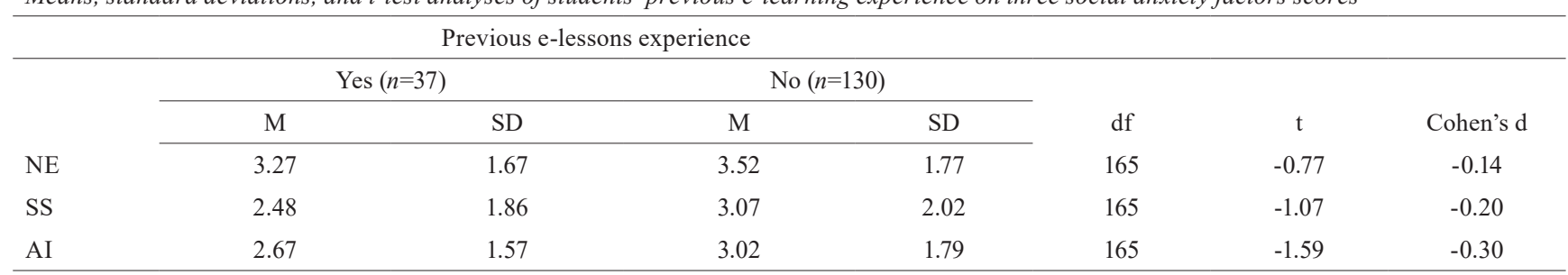

Note. The skewness values of each variable ranged from +0.45 to +1.06 while the kurtosis values ranged from -0.96 to +0.25 . This indicates that a normal distribution is achieved (Tabachnick \& Fidell, 2013). NE: Negative evaluation, SS: Somatic symptoms, AI: Avoidance of interaction 


\subsection{Is there a statistically significant difference between students' not listening to teachers actively at live synchronous lessons regarding social anxiety scores?}

An independent sample t-Test was used to test for social anxiety factors among students' not listening teachers actively at synchronous online lessons (See Table 5). Only the avoidance of interaction sub-factor scores of the social anxiety for students differs significantly, [NE: $t(165)=.10, \mathrm{p}=.92, \mathrm{~d}=.41$; SS: $t(165)=-0.65, \mathrm{p}=.52, \mathrm{~d}=.47$; AI: $t(165)=-2.20, \mathrm{p}=.02, \mathrm{~d}=.40]$. The means of avoiding interaction for the students who stated that they did not actively listen to the teacher in the synchronous lessons group ( $M=3.72)$ was significantly higher than the other group ( $M=2.83)$ with the medium Cohen's d effect size.

Table 5

Means, standard deviations, and t-test analyses of students who not listening teacher actively at synchronous online lessons on three social anxiety factor scores

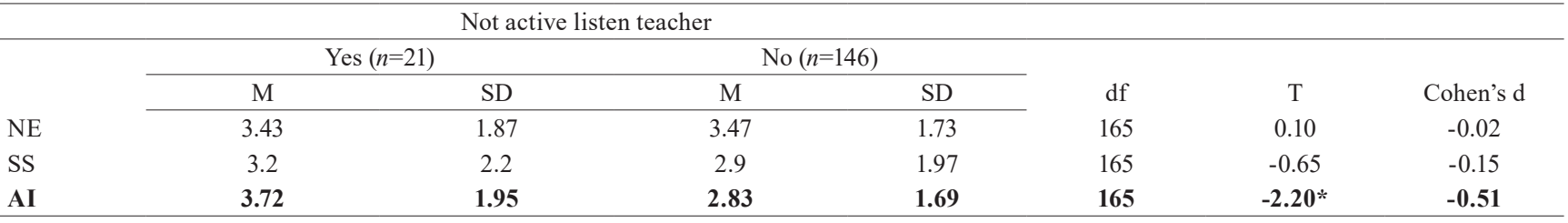

Note. The skewness values of each variable ranged from +0.42 to +0.78 while the kurtosis values ranged from -1.04 to -0.45 . This indicates that a normal distribution is achieved (Tabachnick \& Fidell, 2013). NE: Negative evaluation, SS: Somatic symptoms, AI: Avoidance of interaction, * used for p<.05

\subsection{Is there a statistically significant difference between using chat in synchronous lessons and social anxiety?}

An independent sample t-Test was used to test for social anxiety factors among students using chat in synchronous lessons (See Table 6). The avoidance of interaction and somatic symptoms sub-factors scores of the social anxiety for students differ significantly, $[\mathrm{NE}: t(165)=.97, \mathrm{p}=.34, \mathrm{~d}=.27$; SS: $t(159)=2.61, \mathrm{p}=.01, \mathrm{~d}=.30$; AI: $t(165)=2.17, \mathrm{p}=.03$, $\mathrm{d}=.27$ ]. The means for not using chat group was significantly higher than using chat group with the medium Cohen's d effect size. These findings show that using the chat feature in synchronous lessons increases the anxiety of communicating with the teacher.

Table 6

Means, standard deviations, and t-test analyses of using chat in synchronous lessons on three social anxiety factor scores

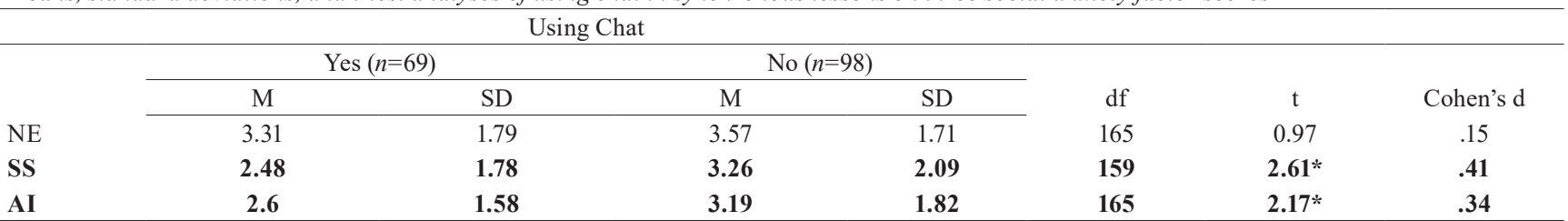

Note. The skewness values of each variable ranged from +0.39 to +1.22 while the kurtosis values ranged from -1.2 to +0.42 . This indicates that a normal distribution is achieved (Tabachnick \& Fidell, 2013). NE: Negative evaluation, SS: Somatic symptoms, AI: Avoidance of interaction * used for $\mathrm{p}<.05$

\subsection{Is there a statistically significant difference between using a microphone in synchronous lessons and social anxiety?}

An independent sample t-Test was used to test for social anxiety factors among students using a microphone in synchronous lessons (See Table 7). Social anxiety factors' scores for students do not differ significantly, $[\mathrm{NE}: t(165)=-.36, \mathrm{p}=.72, \mathrm{~d}=.48$; SS: $t(165)=-.29, \mathrm{p}=.77, \mathrm{~d}=.50 ; \mathrm{AI}: t(165)=1.17, \mathrm{p}=.51, \mathrm{~d}=.44]$. 
Table 7

Means, standard deviations, and t-test analyses of using a microphone in synchronous lessons on three social anxiety factor scores

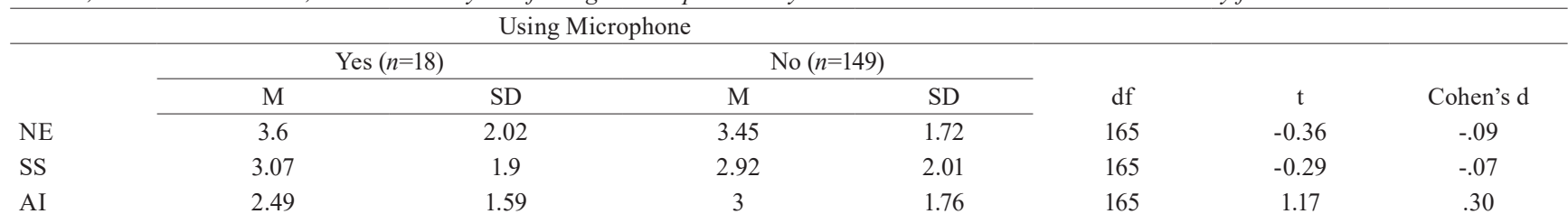

Note. The skewness values of each variable ranged from +0.42 to +1.49 while the kurtosis values ranged from -1.27 to +2.48 . This indicates that a normal distribution is achieved (Tabachnick \& Fidell, 2013). NE: Negative evaluation, SS: Somatic symptoms, AI: Avoidance of interaction

\section{DISCUSSION}

In this study, the social anxiety of university students in their communication with the teacher in synchronous learning environments was examined in terms of various variables. Research findings reveal a low-level negative relationship between students' digital literacy scores and social anxiety levels in synchronous lessons. In other words, as the digital literacy knowledge of students increases, social anxiety in synchronous lessons decreases. This result is consistent with the studies in the literature (Hill et al., 2009; Yang et al., 2010). Synchronous learning environments require some technical skills such as accessing lessons, controlling the camera and microphone, and using chat. This result may be explained by the lack of technical skills leading to social anxiety.

Another result from these findings shows that female students experience significantly more social anxiety than male students. This result is generally consistent with the literature in the field (Ağırtaş \& Güler, 2020). As stated in the literature, this result indicates that due to some biological, genetic, and social factors, it may cause girls to experience more anxiety than boys (McLean \& Anderson, 2009).

How students interact with the teacher in synchronous lessons may also be related to social anxiety. The results show that students who stated that they did not actively listen to the lessons experienced significantly more anxiety in avoiding the interaction dimension of social anxiety. This situation shows that students who experience anxiety may cause them not actively participate in classes. It is about sending a message to the teacher instantly via chat, another form of interaction. Students who do not use speech in physical symptoms of social anxiety and avoidance of interaction experience significantly more social anxiety than those who use it. This situation seems consistent with the previous result. This may be because students think that what will be written will be misunderstood or that they will write something wrong. These results are different from the literature. While studies emphasize that online learning environments reduce anxiety (Rapp-McCall \& Anyikwa, 2016; Reagan, 2018), the opposite situation has emerged in this study. This may be due to the studies in the literature examining anxiety in asynchronous learning environments. In this study, in which social anxiety in synchronous learning environments was examined, students were present with their natural characters, not anonymous, according to asynchronous learning environments (Grieve et al., 2017). This may cause them to experience more anxiety in expressing themselves.

There was no difference in social anxiety between students who use a microphone for live voice conversation and those who do not. This result maybe because the number of students using the microphone in the sample is considerably more thoughtful than the group that does not. On the other hand, studies show that various pedagogical and technical applications in live lessons can reduce students' anxiety (Chen \& Lee, 2011; Satar \& Özdener, 2008). However, the findings obtained differ from the literature. To better understand this difference, it is thought that a more detailed study is needed to explain social anxiety in synchronous lesson practices without any intervention.

Studies indicate that previous experience may reduce anxiety (Sharifrazi, 2012). Unlike the literature, the results of this study show that the social anxiety of students who have previously had an asynchronous learning experience and an e-learning experience does not differ significantly from those who have not. This situation may be related to the lack of long-term experiences of the students. 


\section{CONCLUSION}

The increasing use of synchronous online learning environments reveals the importance of student-teacher interaction in these environments. This research focuses on student anxiety in synchronous learning environments, researched in limited numbers in the literature. The results obtained from the study once again reveal the importance of digital competencies and gender in the synchronous learning environment. These results show that in the light of the increasingly widespread use of distance education, students should be equipped with digital literacy skills at an early age. In addition, creating social communication environments where students will have a positive experience at the beginning of online learning processes may make students experience less anxiety in synchronous lessons. Additional research is needed to understand the relationship between social anxiety and communication and interaction elements that affect students' success and satisfaction in online learning environments.

Peer-review: Externally peer-reviewed.

Ethics Committee Approval: Ethics committee approval for this study was obtained from Karadeniz Technical University (No: E-82554930-050.02.04-114574-413).

Conflict of Interest: The author has no conflict of interest to declare.

Grant Support: The author declared that this study has received no financial support.

Hakem Değerlendirmesi: Dış bağımsız.

Etik Komite Onayı: Bu çalışma için etik komite onayı Karadeniz Teknik Üniversitesi’nden alınmıştır (Sayı: E-82554930-050.02.04-114574-413)

Çıkar Çatışması: Yazar çıkar çatışması bildirmemiştir.

Finansal Destek: Yazar bu çalışma için finansal destek almadığını beyan etmiştir.

\section{References/Kaynaklar}

Ağırtaş, A., \& Güler, Ç. (2020). Sosyal Medya Kullanan Üniversite Öğrencilerinin İnternet Bağımlılı̆̆ı ve Sosyal Kaygı Durumlarının Değerlendirilmesi. Çă̆ Üniversitesi Sosyal Bilimler Dergisi, 17(1), 76-89.

Ajmal, M., \& Ahmad, S. (2019). Exploration of Anxiety Factors among Students of Distance Learning: A Case Study of Allama Iqbal Open University. Bulletin of Education and Research, 41(2), 67-78.

Aktan, E. (2018). Sosyal medya ve sosyal kaygı: Sosyal medya kullanıcıları üzerine bir araştırma. Selçuk Illetişim, 11(2), 35-53.

Alhabeeb, A., \& Rowley, J. (2018). E-learning critical success factors: Comparing perspectives from academic staff and students. Computers \& Education, 127, 1-12. https://doi.org/10.1016/j.compedu.2018.08.007

Amichai-Hamburger, Y., \& Furnham, A. (2007). The positive net. Computers in Human Behavior, 23(2), $1033-1045$.

Chen, C. M., \& Lee, T. H. (2011). Emotion recognition and communication for reducing second-language speaking anxiety in a web-based one-to-one synchronous learning environment. British Journal of Educational Technology, 42(3), 417-440.

Chou, C. (2003). Interactivity and interactive functions in web-based learning systems: a technical framework for designers. British journal of educational technology, 34(3), 265-279. https://doi.org/10.1111/1467-8535.00326

Coryell, J. E., \& Clark, M. C. (2009). One right way, intercultural participation, and language learning anxiety: A qualitative analysis of adult online heritage and nonheritage language learners. Foreign Language Annals, 42(3), 483-504.

D’Errico, F., Paciello, M., \& Cerniglia, L. (2016). When emotions enhance students' engagement in e-learning processes. Journal of e-Learning and Knowledge Society, 12(4).

Fawaz, M., \& Samaha, A. (2021). E-learning: Depression, anxiety, and stress symptomatology among Lebanese university students during COVID-19 quarantine. Nursing Forum, 56(1), 52-57. https://doi.org/10.1111/nuf.12521

Fuller, R. M., Vician, C., \& Brown, S. A. (2006). E-learning and individual characteristics: The role of computer anxiety and communication apprehension. Journal of Computer Information Systems, 46(4), 103-115.

Grieve, R., Kemp, N., Norris, K., \& Padgett, C. R. (2017). Push or pull? Unpacking the social compensation hypothesis of Internet use in an educational context. Computers \& Education, 109, 1-10. https://doi.org/10.1016/j.compedu.2017.02.008

Gündüz, A., Aydemir, M., \& Karaman, S. (2018). Eş-Zamanlı sanal sınıf ortamındaki uzaktan eğitim öğrencilerinin sosyal bulunuşluk düzeylerinin demografik değişkenler açısından incelenmesi. Sakarya University Journal of Education, 8(2), 83-95.

Gürbüz, S., \& Şahin, F. (2018). Sosyal Bilimlerde Araştırma Yöntemleri Felsefe-Yöntem-Analiz (5th ed.). Seçkin.

Havelka, D., Beasley, F., \& Broome, T. (2004). A study of computer anxiety among business students. American Journal of Business, 19(1), 63-71. https:// doi.org/10.1108/19355181200400007

Hill, J. R., Song, L., \& West, R. E. (2009). Social learning theory and web-based learning environments: A review of research and discussion of implications. American Journal of Distance Education, 23(2), 88-103. https://doi.org/10.1080/08923640902857713

Hillman, D. C. A., Willis, D. J., \& Gunawardena, C. N. (1994). Learner-Interface interaction in distance education: An extension of contemporary models and strategies for practitioners. American Journal of Distance Education. 8(2), 30-42 https://doi.org/10.1080/08923649409526853 
Hutchins, N., Allen, A., Curran, M., \& Kannis-Dymand, L. (2021). Social anxiety and online social interaction. Australian Psychologist, $56(2), 142-153$. https://dx.doi.org/10.1089\%2Fcyber.2011.0015

JASP Team. (2020). JASP (Version 0.14.1)[Computer software].

Johnson, G. M. (2006). Synchronous and asynchronous text-based CMC in educational contexts: A review of recent research. TechTrends, 50(46). https:// doi.org/10.1007/s11528-006-0046-9

Keskin, S., Şahin, M., Uluç, S., \& Yurdugul, H. (2020). Online learners’ interactions and social anxiety: The social anxiety scale for e-learning environments (SASE). Interactive Learning Environments, 1-13. https://doi.org/10.1080/10494820.2020.1769681

Korucu, A. T., \& Gürkez, Ş. (2019). An analysis of online privacy concerns of teacher candidates. Participatory Educational Research, 6(2), 15-25.

Kumar Basak, S., Wotto, M., \& Bélanger, P. (2018). E-learning, M-learning and D-learning: Conceptual definition and comparative analysis. E-Learning and Digital Media, 15(4), 191-216. https://doi.org/10.1177/2042753018785180

McLean, C. P., \& Anderson, E. R. (2009). Brave men and timid women? A review of the gender differences in fear and anxiety. Clinical psychology review, 29(6), 496-505.

Mertens, D., 2010. Research and evaluation in education and psychology. 3rd ed. Los Angeles: Sage, pp.151-152.

Moore, M. (1997). Theory of transactional distance. In D. Keegan (Eds.), Theoretical Principles of Distance Education (pp. 22-38). Routledge.

Morrison, J. (2016). DSM-5'i Kolaylaştıran: Klinisyenler İçin Tanı Rehberi (M. Şahin, Ed. \& H. Uğur Kural, Trans.), Nobel Akademik Yayıncılık (Original work published 2014).

Orhan, G., \& Beyhan, Ö. (2020). Teachers' perceptions and teaching experiences on distance education through synchronous video conferencing during covid-19 pandemic. Social Sciences and Education Research Review, 7(1), 8-44.

Park, Y. J., \& Bonk, C. J. (2007). Synchronous learning experiences: Distance and residential learners' perspectives in a blended graduate course. Journal of Interactive Online Learning. 6 (3), 245-264.

Persons, J. B., \& Tompkins, M. A. (2011). Cognitive-Behavioral Case Formulation. In T. D. Eells (Ed.), Handbook of Psychotherapy Case Formulation (Second Edition, p. 307). Guilford Publications.

Pierce, T. (2009). Social anxiety and technology: Face-to-face communication versus technological communication among teens. Computers in Human Behavior, 25(6), 1367-1372.

Privitera, G. J. (2012). Statistics for the Behavioral Sciences. Sage Publications, Inc.

Radha, R., Mahalakshmi, K., Kumar, V. S., \& Saravanakumar, A. R. (2020). E-Learning during Lockdown of Covid-19 Pandemic: A Global Perspective. International Journal of Control and Automation. 13(4), 1088-1099.

Rapp-McCall, L. A., \& Anyikwa, V. (2016). Active learning strategies and instructor presence in an online research methods course: Can we decrease anxiety and enhance knowledge? Advances in Social Work, 17(1), 1-14.

Reagan, A. R. (2018). Teaching Undergraduate Social Statistics Online: A Classroom Assessment of Instructional Interventions to Reduce Statistics Anxiety and Facilitate Student Success. J. Educ. Soc. Policy, 5.

Saadé, R. G., \& Kira, D. (2009). Computer anxiety in e-learning: The effect of computer self-efficacy. Journal of Information Technology Education: Research, 8(1), 177-191.

Saadé, R. G., Kira, D., Mak, T., \& Nebebe, F. (2017, June). Anxiety \& Performance in Online Learning. In In SITE 2017: Informing Science+ IT Education Conferences: Vietnam (pp. 147-157).

Satar, H. M., \& Özdener, N. (2008). The effects of synchronous CMC on speaking proficiency and anxiety: Text versus voice chat. The Modern Language Journal, 92(4), 595-613.

Sharifrazi, F. (2012). The Investigation of a Synchronous Engagement System (SES) to Alleviate Anxiety Among eLearning Students in an MBA Program [Doctoral dissertation]. Nova Southeastern University.

Song, L. (2005). Self-directed learning in online environments process, personal attribute, and context [Doctoral dissertation]. The University of Georgia.

Song, L., Singleton, E. S., Hill, J. R., \& Koh, M. H. (2004). Improving online learning: Student perceptions of useful and challenging characteristics. The Internet and Higher Education, 7(1), 59-70.

Stewart, A. R., Harlow, D. B., \& DeBacco, K. (2011). Students' experience of synchronous learning in distributed environments. Distance Education, 32(3), 357-381. https://doi.org/10.1080/01587919.2011.610289

Tabachnick, B. G., \& Fidell, L. S. (2013). Using multivariate statistics (6th ed). Pearson Education.

Üstündağ, M. T., Güneş, E., \& Bahçivan, E. (2017). Turkish adaptation of digital literacy scale and investigating pre-service science teachers' digital literacy. Journal of Education and Future, 12, 19-29.

Warden, C. A., Stanworth, J. O., Ren, J. B., \& Warden, A. R. (2013). Synchronous learning best practices: An action research study. Computers and Education, 63, 197-207. https://doi.org/10.1016/j.compedu.2012.11.010

Wongwatkit, C., Panjaburee, P., Srisawasdi, N., \& Seprum, P. (2020). Moderating effects of gender differences on the relationships between perceived learning support, intention to use, and learning performance in a personalized e-learning. Journal of Computers in Education, 7(2), 229-255. https:// doi.org/10.1007/s40692-020-00154-9

Yang, H., Lay, Y., Tsao, W., \& Lay, J. S. (2010). The impact of Internet on social anxiety and learning adaptability for young adult Internet users. International Conference on e-Business (ICE-B), Greece,1-4. 
